\title{
EFFECT OF " BUTRALIN HERBICIDE " INJECTED THROUGH DRIP IRRIGATION SYSTEMS ON CUCUMBER RESIDUES AND PRODUCTIVITY
}

\author{
EL-SHAZLY, A. M., M. M. MOUSTAFA AND WAEL M. SULTAN
}

Agricultural Engineering Research Institute, ARC, Dokki - Giza

(Manuscript received 10 February 2009)

\begin{abstract}
The herbicide butralin (Amex) was injected at the recommended rate ( $2.5 \mathrm{Kg} / \mathrm{fed})$ through subsurface and surface drip irrigation systems with two flow rates of 8 and $12 \mathrm{lph} / \mathrm{m}$ under sandy soil conditions of the newly reclaimed areas of Egypt.

Maximum cucumber yield of $8360 \mathrm{~kg} / \mathrm{fed}$. was achieved using subsurface drip irrigation systems at $8 \mathrm{lph} / \mathrm{m}$ flow rate and $50 \mathrm{~cm}$ emitters spacing, in manure sandy soil Water use efficiency (WUE) ranged from 4.042 to $3.955 \mathrm{~kg} / \mathrm{m}^{3}$ with 8 and $12 \mathrm{lph} / \mathrm{m}$ flow rates, respectively for subsurface irrigation systems 50 and $33 \mathrm{~cm}$ emitters spacing in manured sandy soil. The application of herbicide butralin (Amex) with subsurface drip irrigation systems, $50 \mathrm{~cm}$ emitters spacing proved more suitable to increase cucumber yield, and to achieve more uniformity in water distribution ( 8 $\mathrm{Iph} / \mathrm{m}$ ) for irrigation systems. No butralin (Amex) residues were detected in cucumber yield produced under subsurface drip irrigation systems at $10 \mathrm{~cm}$ depth for the $50 \mathrm{~cm}$ emitters spacing and $8 \mathrm{lph} / \mathrm{m}$ flow rate.
\end{abstract}

\section{INTRODUCTION}

Application of pesticide through a drip irrigation system adds a new dimension to irrigation system and becomes a multifunction unit able to supply crops with necessary water and agrochemicals at the same time (El-Gindy and El-Araby, 1996 and Locascio et al., 1997).

The excessive use of both water and agro-chemicals is contributing an environmental problem and human health hazard. So the cultivation in new reclaimed land with modern irrigation techniques such as drip irrigation systems and chemigation and/or fertigation will play great role in eliminating this problem.

The government encourage private sector to increase vegetable crops production in the reclaimed land specially cucumber. The cucumber area reached 12889 Fed in 2003 compared with 8318 Fed, recorded at 1995 which represent 35\% increase in that crop area within that period (Agricultural Statistics, 2003).

The emitter's line materials and other equipment must be resistant to chemicals that may be injected into irrigation system, such as fertilizers, bactericides, insecticides, herbicides and fungicides (Nakayama et al., 1979). 
The application of pesticides through an irrigation system (Pestigation) from a drip source is not prone to aerial drift away from the treated area as in the case with sprinkler and sprayer application. Also, there is less potential for pesticide transport by runoff and erosion because of the absence of their pesticide residues on the plant and soil surfaces to wash off (Threadgill, et al., 1990).The applications of butralin (3000 p.p.m.) increased shoot growth in the tree head and stem thickening (Quinlan and Pakenham,1984). The control of C. album and S. nigrum was achieved with butralin by $94 \%$ and increased yields by $17-29 \%$ in soybeans (Regnault, 1986). Low rates of butralin did not control the weed, but normal recommended doses resulted in 85\% control. (Demirci and Nemli, 1996).

The aim of this study was to mitigate pesticide contamination and residues in cucumber under newly reclaimed land by using drip irrigation systems and herbicide use.

\section{MATERIALS AND METHODS}

\section{1-Experimental design and layout:}

An experiment was carried out during 2003-2004 seasons at El-Bustan-Farm , Nobaria sector, Abd-El- Monem Reyad village in western desert of Egypt, about 130 $\mathrm{km}$ northwest of Cairo. The area is characterized arid soil with dry weather. The experimental field belongs to Agricultural Engineering Research Institute, Ministry of Agriculture and land Reclamation.

The experimental area of $400 \mathrm{~m}^{2}(20 \mathrm{~m} \times 20 \mathrm{~m})$ was divided into two plots $10 \times 20 \mathrm{~m}$ for surface and subsurface drip irrigation systems (Fig1). Every plot was divided into four subplots. The first two subplots were adjusted under $8 \mathrm{lph} / \mathrm{m}$ flow rate with sandy soil and its mixture with manure. The second two subplots were arranged under $12 \mathrm{lph} / \mathrm{m}$ flow rate with sandy soil and its mixture with manure. Every plot was treated by butralin herbicide (Amex) through the injection with the drip irrigation systems by using positive displacement magnetic pump. Treatment was done one month after planting as a protection approach. Cucumber seeds crops were sown on 20 June, 2004.

\section{2- Herbicide characteristics}

According to The Ministry of Agriculture (Agricultural Statistics (2003)., (Butralin) herbicide was applied at the recommended rate $(2.5 \mathrm{~kg} / \mathrm{fed})$. The Agrochemical Hand Book, (1985). Butralin has the following characteristics:

-Molecular formula: $\mathrm{C}_{12} \mathrm{H}_{21} \mathrm{~N}_{3} \mathrm{O}_{4}$

-Common name: BUTRALIN

-Chemical name: 
4-(1,1-dimethylethyl)-N-(1-methylpropyl)- 2,6-dinitrobenzenamine

- Trade mark name: AMEX 820

- Solubility in water: $0.3 \mathrm{mg} / \mathrm{I}\left(25^{\circ} \mathrm{C}\right)$

-Toxicity classification (WHO) of formulation: Law III

-Environmental Fate in soil: 21 days.

-EPA classification: IV

-Toxicity: Male rat (Oral) LD 50 1170, female rats 1049 mg/Kg.

Inhalation $\mathrm{LC}_{50}$ for rats $>9.35 \mathrm{mg} / \mathrm{L}$ of air.

-Recommended tolerance:

Code of federal register EPA revised July $1,83: 0.1 \mathrm{p} \mathrm{p} \mathrm{m}$.

\section{3-Sampling, extraction, clean - up and determination of butralin residues in plants:}

A- Extraction: 1- Weigh a 50 gram soil into a 250-ml Erlenmeyer flask with a ground glass top.2- Add $100 \mathrm{ml}$ dichloromethane (DCM) to the ground glass stopper 30 minutes.3- Prepare a glass funnel by plugging the spout with glass wool and place the funnel into a $500-\mathrm{ml}$ separatory funnel.4- Decant the extract through the funnel into the separatory funnel.5- Repeat steps 2 and 4, this time adding the soil into the funnel.6-Rinse the Erlenmeyer with $25 \mathrm{~m}-\mathrm{I}$ DCM and pour through the soil in the funnel discard soil in the funnel.7-Add $50 \mathrm{~m}$-I DIUF water to the separatory funnel and shake vigorously for 1 minute and allow the phases to separate. Filler the DCM layer through a glass funnel containing $2.5 \mathrm{~cm}$ of anhydrous sodium sulfate supported by a glass wool plug into a

500-ml boiling flask.8- Add $50-\mathrm{ml} \mathrm{DCM}$ to the separatory funnel containing the water. Shake for 1 minute and allow the phases to separate. Filler the DCM layer through the same glass funnel containing sodium sulfate used in step 7. 9- Concentrate the extract to $1-5-\mathrm{ml}$ by rotary evaporation at $30-35^{\prime} \mathrm{c} .10$ - Further concentrate the extract to just dryness with a gentle stream of nitrogen.11- Reconstitute the residue by adding 50-ml of $10 \%$ ethy 1 acetate in hexane, capping the flask and swirling to dissolve the residue.12- Remove a portion of the extract by Pasteur pipet and place into an auto sample vial for GC analysis.

\section{B-Analysis by GC/ECD}

Instrumentation and operating conditions for the analysis of soil for butralin and 4tert-buty1- 2,6- dinitroaniline are as follows:-

Instrument: Hewlett Packard 5890 Series II with a 7673 A autosampler

Column:J\& W D B 1701

Length: $30 \mathrm{~m}$ 
LD : 0, $32 \mathrm{~mm}$

Film Thichness: 0,25um

Oven Temperature: $150^{\circ} \mathrm{C}$ hold for 5 minutes

Ramp to $160{ }^{\circ} \mathrm{C}$ for 20 minutes.

Hold $160^{\circ} \mathrm{C}$ at $20^{\circ} \mathrm{C} /$ minutes .

Ramp to $280^{\circ} \mathrm{C}$ at $20^{\circ} \mathrm{C}$ minutes.

Hold at $280^{\circ} \mathrm{C}$ for 2 minutes.

Detector: Electron Capture

Temperature: $300^{\circ} \mathrm{C}$

Make-up Gas: Nitrogen (total flow $=60 \mathrm{ml} / \mathrm{min}$ )

Inlet : Split less

Injector Temperature: $230^{\circ} \mathrm{C}$

Carrier Gas: Helium@2.0ml/min.

Injection volume: 4.ul.

Retention Times: butralin: approximately 28 minutes

4- tert-buty1- 2, 6- dinitroaniline: approximately

23 minutes.

\section{C-Fortification of Samples}

Prepare individual $1.0 \mathrm{mg} / \mathrm{ml}$ stock of butralin and 4-tert-butyl-2.6-dinitroaniline by accurately weighing each reference standard material into an appropriate vial. Adjust actual weight of the compound for purity to determine the volume of hexane to be added.

Prepare mixed working fortification solutions at following levels in hexane for fortification of samples:

\begin{tabular}{|cc|}
\hline p.p.m level & $\begin{array}{c}\text { Concentration of fortification } \\
\text { Solution }(\mathrm{ug} / \mathrm{ml})\end{array}$ \\
\hline 0.1 & 0.5 \\
\hline 0.05 & 2.5 \\
\hline 0.10 & 5.00 \\
\hline 0.50 & 25.00 \\
\hline
\end{tabular}

To prepare fortified soil samples, add $1.0 \mathrm{ml}$ of the appropriate fortification solutions to 50 grams of sample.

\section{D-Preparation of GC Standard Solutions}

Prepare individual $1.0 \mathrm{mg} / \mathrm{ml}$ stock of butralin and 4-tert-butyl-2.6-dinitroaniline by accurately weighing each reference standard material into an appropriate vial. 
Adjust actual weight of the compound for purity to determine the volume of $10 \%$ ethyl acetate in to be added. Prepare mixed working solutions at the following levels in $10 \%$ ethyl acetate in hexane for GC standards: The concentration of used fortification solutions $(\mu \mathrm{g} / \mathrm{ml})$ were $0.0,0.01,0.02,0.04,0.1,0.2$ and 0.5.The above solution is analyzed concurrently with samples for quantitation purposes (Jeff, 1994).

4-Determination of yield: Yield $=$ Average weight fruit/ plant $\times$ Number of plant/fed

5- Amount of irrigation water Applied: The amount of applying irrigation water was according to the Central Laboratory for Agricultural Climate, Ministry of Agriculture and land Reclamation.

6-Determination of water use efficiency (W.U.E): Crop water use efficiency W.U.E. ( $\mathrm{kg} / \mathrm{m}^{3}$ ) has been used to describe the relationship between total yield and total applied water, and it was determined according to the following equation:

$$
\text { W.U.E. }=\mathrm{Y} / \mathrm{W}
$$

Where: W.U.E. =Water use efficiency $\left(\mathrm{kg} / \mathrm{m}^{3}\right), \quad \mathbf{Y}=$ Yield $(\mathrm{kg} / \mathrm{fed})$ and $\mathbf{W}=$ Applied water $\left(\mathrm{m}^{3} / \mathrm{fed}\right)$.

7-Determination of pesticide residues in cucumber fruits by Gc- chromatograms: Determination of butralin (Amex) residues in cucumber fruits by Gc- chromatograms according to the Laboratory of Environmental Research Unit of Toxicology, Faculty of Agriculture, Ain-Shams University.

\section{RESULTS AND DISCUSSION}

\section{1- Effect of drip irrigation systems on cucumber productivity under}

herbicide use: Results of table (1) revealed that the productivity of cucumber (kg / fed) was significantly affected by drip irrigation systems, emitters spacing, flow rates, and injected pesticide to the soil through irrigation. The highest yield value (8360 $\mathrm{kg} / \mathrm{fed}$ ) was obtained using the subsurface drip irrigation systems (10 cm depth), 50 $\mathrm{cm}$ emitters spacing, sand soil mix with manure and of $8 \mathrm{l} / \mathrm{h} / \mathrm{m}$ flow rate with the herbicide butralin (Amex).The yield increase by $11.4 \%$ as compared to no applied herbicide with the drip irrigation systems. This may be due to the improved performances of using the new techniques of herbigation. (Agarcio,BC, Jr.1985).On the other hand, the lowest value $(7030 \mathrm{Kg} / \mathrm{fed})$ was obtained by using the same herbicide irrigated by surface drip systems, $33.3 \mathrm{~cm}$ emitters spacing , $12 \mathrm{lph} / \mathrm{m}$ flow rate in sandy soil .The yield decreased by $6.3 \%$ as compared to no applied herbicide with the drip irrigation systems. This may be explained due to the great interference between chemicals in the area of the root zone. Data in the same table showed that the productivity with $12 \mathrm{lph} / \mathrm{m}$ flow rate was less than that of $8 \mathrm{lph} / \mathrm{m}$ flow rate. This 
may be attributed to the good performances of both tested drip irrigation systems and herbigation process in improving the water use efficiency and prevention weeds to share the nutriment with cucumber plants.

Table 1. Effect of butralin herbicide application through drip irrigation systems on cucumber productivity.

\begin{tabular}{|c|c|c|c|c|}
\hline \multirow[b]{2}{*}{$\begin{array}{c}\text { Irrigation } \\
\text { system }\end{array}$} & \multirow[b]{2}{*}{ Soil condition } & \multirow[b]{2}{*}{$\begin{array}{c}\text { Applied flow } \\
\text { rate } 1 / \mathrm{h} / \mathrm{m}- \\
\text { tube }\end{array}$} & \multicolumn{2}{|c|}{ Yield } \\
\hline & & & $\mathrm{kg} / \mathrm{fed}$ & $\begin{array}{c}\text { Relative } \\
\text { productivity\% }\end{array}$ \\
\hline \multirow{4}{*}{ Surface drip } & \multirow{2}{*}{$\begin{array}{c}\text { Without } \\
\text { amendments }\end{array}$} & 8 & 8000 & 106.6 \\
\hline & & 12 & 7030 & 93.7 \\
\hline & \multirow[t]{2}{*}{$\begin{array}{c}\text { With } \\
\text { amendments }\end{array}$} & 8 & 8140 & 108.5 \\
\hline & & 12 & 8080 & 107.7 \\
\hline \multirow{4}{*}{$\begin{array}{l}\text { Subsurface } \\
\text { drip }\end{array}$} & \multirow[b]{2}{*}{$\begin{array}{c}\text { Without } \\
\text { amendments }\end{array}$} & 8 & 8070 & 107.6 \\
\hline & & 12 & 7930 & 105.7 \\
\hline & \multirow[b]{2}{*}{$\begin{array}{c}\text { With } \\
\text { amendments }\end{array}$} & 8 & 8360 & 111.4 \\
\hline & & 12 & 8100 & 108.0 \\
\hline Control & \multicolumn{4}{|l|}{$7500 \mathrm{~kg} / \mathrm{fed}$} \\
\hline
\end{tabular}

Farm manure was added to sandy soils with $20 \mathrm{~kg} / \mathrm{fed} \quad$ Relative productivity $\%=$ Treatment $/$ Control $* 100$

2- Water use efficiency as affected by drip irrigation systems for cucumber under herbicide use: Data in table (2) showed that water use efficiency by cucumber plants was markedly affected by the irrigation systems characteristics and herbigation treatment. The herbicide butralin (Amex) when used showed the highest values of WUE $\left(4.042\right.$ and $\left.3.955 \mathrm{~kg} / \mathrm{m}^{3}\right)$ at 8 and $12 \mathrm{lph} / \mathrm{m}$ flow rates when cucumber was irrigated by subsurface irrigation systems, sand soil with manure and emitters spacing of 50 and $33.3 \mathrm{~cm}$. WUE was increased by $11.4 \%$ as compared with the control. Whereas the systems with 8 and12 $\mathrm{lph} / \mathrm{m}$ flow rate, 50 and $33.3 \mathrm{~cm}$ emitters spacing for surface drip irrigation systems showed intermediate performances ( $3.936-3.907 \mathrm{~kg} / \mathrm{m}^{3}$ ). The other treatments gave the lowest values between(3.399 to3.868 $\mathrm{kg} / \mathrm{m}^{3}$ ). These results were in agreement with Adamson, 1989 who reported that the use of subsurface trickle irrigation system leads to increase crop yield for peanut as well as water use efficiency. 
Table 2. Effect of butralin herbicide application through drip irrigation systems on cucumber Water use efficiency WUE $\left(\mathrm{Kg} / \mathrm{m}^{3}\right)$.

\begin{tabular}{|c|c|c|c|c|}
\hline \multirow[b]{2}{*}{ Irrigation system } & \multirow[b]{2}{*}{ Soil condition } & \multirow[b]{2}{*}{$\begin{array}{c}\text { Flow rate } \mathrm{l} / \mathrm{h} / \mathrm{m} \text { - } \\
\text { tube }\end{array}$} & \multicolumn{2}{|c|}{ WUE } \\
\hline & & & $\left(\mathrm{Kg} / \mathrm{m}^{3}\right)$ & Difference \% \\
\hline \multirow{4}{*}{ Surface drip } & \multirow{2}{*}{$\begin{array}{c}\text { Without } \\
\text { amendments }\end{array}$} & 8 & 3.868 & $6.6 \%$ \\
\hline & & 12 & 3.834 & $-2.3 \%$ \\
\hline & \multirow[t]{2}{*}{ With amendments } & 8 & 3.936 & $8.5 \%$ \\
\hline & & 12 & 3.907 & $7.7 \%$ \\
\hline \multirow{4}{*}{ Subsurface drip } & \multirow[b]{2}{*}{$\begin{array}{c}\text { Without } \\
\text { amendments }\end{array}$} & 8 & 3.902 & $7.6 \%$ \\
\hline & & 12 & 3.399 & $5.7 \%$ \\
\hline & \multirow[b]{2}{*}{ With amendments } & 8 & 4.042 & $11.4 \%$ \\
\hline & & 12 & 3.955 & $8.0 \%$ \\
\hline Control & \multicolumn{4}{|l|}{$3.624 \mathrm{Kg} / \mathrm{m}^{3}$} \\
\hline
\end{tabular}

3-Residues in cucumber fruit produced under drip irrigation systems for

butralin. Data concerning the residues of the herbicide butralin in cucumber produced under drip irrigation systems (subsurface and surface) and herbigation through growing stage of cucumber plants at 8 and $121 \mathrm{ph} / \mathrm{m}$ flow rate are tabulated in Table (3).Examination of the obtained results indicated the absence of herbicide residues in cucumber fruits at harvest as compared to the control (conventional sprayer) under subsurface and surface drip irrigation systems, $8 \mathrm{lph} / \mathrm{m}$ flow rate in manured sandy soils. This may be explained because of the rapid degradation and hydrolysis of butralin herbicide in water and soil Capri et al., 1998 who reported that despite the large number of applications done during the cultivation of the crop no residue was found in the plant or the fruit (quantification limit $<0.01 \mathrm{mg} / \mathrm{kg}$ ). Under these conditions butralin showed a low environmental impact and was of low persistence and mobility in the soil profile.

Table 3. Residues in cucumber fruit produced under drip irrigation systems for butralin.

\begin{tabular}{|c|c|c|c|c|c|c|c|c|c|}
\hline \multirow{4}{*}{$\begin{array}{c}\text { Pesticid } \\
\text { e used }\end{array}$} & \multicolumn{7}{|c|}{ Residues in cucumber in PPb } & \multirow{2}{*}{ subsurface } \\
\cline { 2 - 9 } & $\begin{array}{c}8 \\
\mathrm{IPh} / \mathrm{m}\end{array}$ & $\begin{array}{c}8 \\
\mathrm{IPh} / \mathrm{m}\end{array}$ & $\begin{array}{c}12 \\
\mathrm{IPh} / \mathrm{m}\end{array}$ & $\begin{array}{c}12 \\
\mathrm{IPh} / \mathrm{m}\end{array}$ & $\begin{array}{c}8 \\
\mathrm{IPh} / \mathrm{m}\end{array}$ & $\begin{array}{c}8 \\
\mathrm{IPh} / \mathrm{m}\end{array}$ & $\begin{array}{c}12 \\
\mathrm{IPh} / \mathrm{m}\end{array}$ & $\begin{array}{c}12 \\
\mathrm{IPh} / \mathrm{m}\end{array}$ & $\begin{array}{c}\text { Convent- } \\
\text { ional } \\
\text { spray }\end{array}$ \\
\cline { 2 - 9 } & manur & sand soil & manure & $\begin{array}{l}\text { sand } \\
\text { soil }\end{array}$ & $\begin{array}{l}\text { manur } \\
\mathrm{e}\end{array}$ & $\begin{array}{l}\text { sand } \\
\text { soil }\end{array}$ & manure & $\begin{array}{l}\text { sand } \\
\text { soil }\end{array}$ & \\
\hline $\begin{array}{l}\text { Butralin } \\
\text { (Amex) }\end{array}$ & $<1.0$ & $<1.0$ & $<1.0$ & $<1.0$ & $<1.0$ & $<1.0$ & $<1.0$ & $<1.0$ & $>1.0$ \\
\hline
\end{tabular}

Limit of detection of butralin (LOD =1 ppb)

$M R L=0.1$ PPM (Code of federal register EPA revised July 1,1983$)$ * 


\section{REFERENCES}

1. Adamson,F.J. 1989 . Irrigation method and water quality effects on peanut yield and grade .Agron. 81:589-593.

2. Agarcio, BC, Jr. 1985. Effect of phosphorus and nitrogen fertilization and weed control method on weed incidence and mungbean production.Dep. Agron. and Soil Sci., Visayas State Coll. of Agric., Baybay, Leyte, Philippines. Annals-ofTropical-Research. 1985, 7: 1-11, 12 ref.

3. Agricultural Statistics. 2003. Summer and Nile crop2003, Vol.2 June 2004, pp (191to193).

4. Capri, E., F. Sicbaldi, N. Vagnotti and M. Trevisan. 1998. Ethoprophos residues in soil and in tomato after repeated applications by drip irrigation. Istituto di Chimica Agraria ed Ambientale, Universita Cattolica del Sacro Cuor, via Emilia Parmense 84 - 29100 Piacenza, Italy. Fresenius-Environmental-Bulletin. 1998, 7: 11-12, 734737, 6 ref.

5. Demirci,M. and Y. Nemli. 1996. Pre emergence dinitroanilines for control of bristly foxtail (Setaria verticillata (L.) P.B.) in cotton production areas. dr. Ege Universitesi Ziraat Fakultesi Bitki Koruma Bolumu, 35100 Bornova, Izmir, Turkey. Ege-Universitesi-Ziraat-Fakultesi-Dergisi. 1996, 33: 2-3, 129-134, 14 ref.

6. EL-Gindy, A. M. and A.M. EL-Araby. 1996. Vegetable Crops Response to Surface and Subsurface. International Conference on Evapotranspiration and Irrigation Scheduling, San Antonio, Texas, November 3-6, 1996.

7. Jeff Howard, B.S. 1994. Method of The Determination of Butralin-CFPI. Agrochemical Division 28 Bd. Camelinat 92233 Gennevilliers, FRANVE. PTRL Project No: 774.PTRL REPORT No: 1605. Volume 1 of 1 of Study.

8. Locascio, S.J., J.P. Gilreath, D.W. Dickson, T. A. Kucharek, J. P. Jones and J. W. Noling. 1997. Fumigant alternatives to methy1 bromide for polyethylene-mulched tomato. Hortscience 32(7):1208-1211.

9. Nakayama, F. S., D.A. Bucks and A .J. Clemmers. 1979. Assessing trickle emitter application uniformity. ASAE: 816-821.

10. Quinlan,J.D. and E.M. Pakenham. 1984. Effects of manual and chemical control of lateral shoots on the growth of young ornamental trees. East Malling Research Station, Maidstone ME19 6BJ, UK. Journal of Horticultural Science. 1984, 59: 1, 45-50, 7 ref.

11. Regnault, Y. 1986. Weed control in soybeans. CETIOM, 75116 Paris, France: Information's Techniques, CETIOM. 1986, No.94, supplement, 166-169.

12. The Agrochemicals Hand Book. 1985. The Royal Society of Chemistry. The University Notlingham NG7 2RD ENGLAND .Dec.

13. Threadgill, E.D., D.E. Eisenhauer, J.R. Young and B. Bar-Yosef. 1990. Chemigation. In Management of Farm Irrigation systems, eds. G.J.Hoffman, T.A. Howell, and K.H Solomon, St. Joseph, Mich, :ASAE. 749-775. 


\section{تأثير حقن مبيد الحشائش " بيوترالين " خلال نظم الرى بالتنقيط ومتبقياته على إنتاجية محصول الخيار}

أشرف السيد الثاذلي ، مصطفي محمود مصطفي، وائل محمود سلطان

$$
\text { معهُ بحوث الهندسة الزراعية - مركز البحوث الزراعية - الدقي - الجيزة }
$$

تم تقييم أداء حقن مبيد الحشائش بيوترالين ( أمكس ) من خلال نظامي الرى با لتتقيط السطحى و

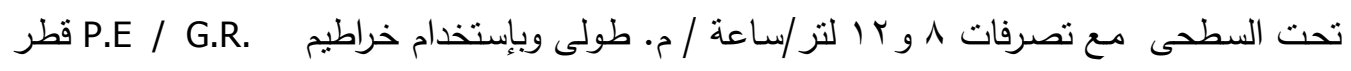

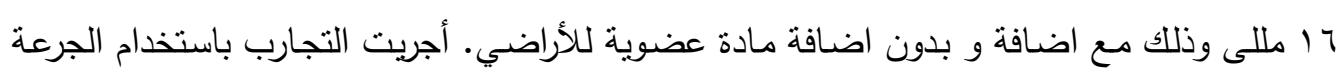

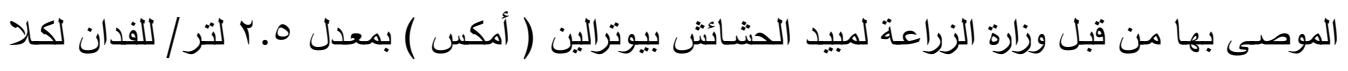

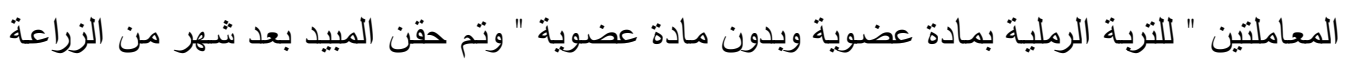
كمعاملة وقائية لمحصول الخيار . لمبن

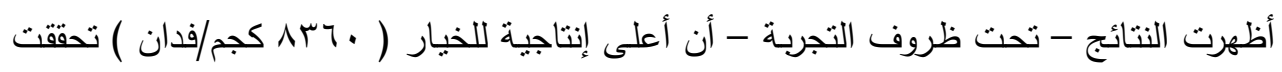

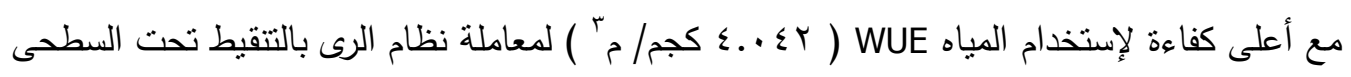

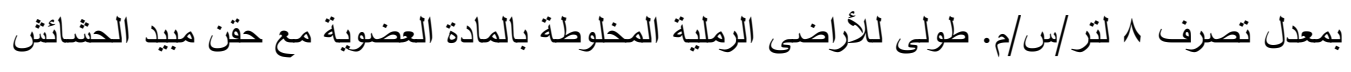

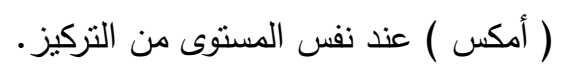

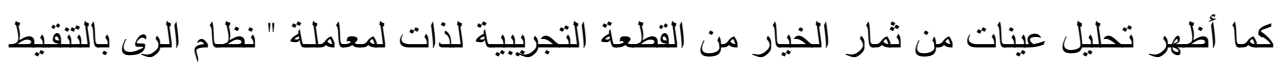

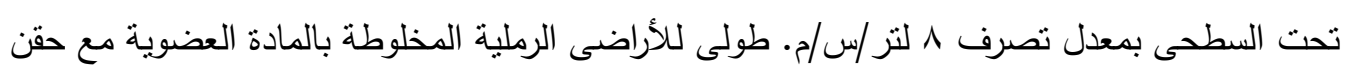

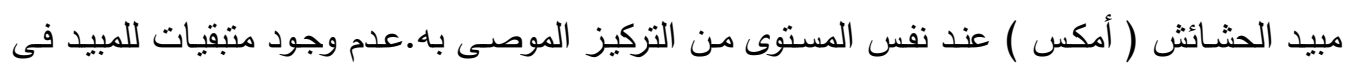
الثمار الناتجة بعد الحصاد. 